\title{
SETING PERILAKU DAN TERITORIALITAS RUANG SEBAGAI PERWUJUDAN ADAB DI MASJID GADING PESANTREN KOTA MALANG
}

\author{
Yulia Eka Putrie dan Luluk.Maslucha \\ UIN Maulana Malik Ibrahim Malang \\ email: ekaputrie.yulia@gmail.com
}

\begin{abstract}
This study concerns behavior setting and territoriality in Masjid Gading Pesantren as a part of the broader research on community based mosques and social interaction within them. The purpose is to identify some unique behavior patterns of the users of Masjid Gading Pesantren from the perspective of behavioral based research in architecture. The methods employed in this research are place-centered mapping, architectural documenting, and informal interview. The finding shows some specific behavioral pattern of the mosque's users derived from the courtesy toward the mosque and the leader of the mosque as well as the pesantren. The behaviors form pattern as they become the tradition or local custom deriving into unique courtesy. Furthermore, this behavioral pattern also shapes the specific territories in the mosque, namely mihrab as a primary territory 'owned' by the kyai and legitimated by the santris. Such unique behavioral pattern belongs to local value which is largely accepted in Islam as long as it does not contradict with syariah.

Penelitian ini mengenai seting perilaku dan teritorialitas ruang di Masjid Gading Pesantren yang merupakan bagian dari penelitian mengenai masjid berbasis masyarakat dan interaksi sosial yang terjadi di dalamnya. Tujuan dari penelitian ini adalah untuk mengetahui kekhasan pola perilaku keruangan santri dan jamaah di Masjid Gading Pesantren dari sudut pandang keilmuan arsitektur perilaku. Penelitian ini menggunakan metode place centered mapping, dokumentasi, dan wawancara informal. Temuan menunjukkan kekhasan pola
\end{abstract}


perilaku keruangan yang disebabkan adanya adab terhadap masjid dan adab terhadap kyai sebagai pemimpin masjid dan pesantren. Perilaku-perilaku ini membentuk pola karena telah menjadi tradisi atau kebiasaan setempat yang menjadi perwujudan yang khas terhadap adab. Lebih jauh, pola perilaku ini juga membentuk teritori-teritori yang khas di masjid tersebut, yaitu area mihrab yang menjadi teritori primer yang 'dimiliki' oleh kyai dan dilegitimasi oleh para santri. Kekhasan perilaku ini dapat dianggap sebagai kearifan lokal yang diterima secara luas keberadaannya di dalam Islam selama tidak bertentangan dengan syariat.

Keywords: territoriality, pesantren's mosque, behavioral setting, adab

\section{Pendahuluan}

Pesantren, merupakan nama yang tidak lepas dari perkembangan sistem pendidikan agama Islam, khususnya di Indonesia. Sampai saat ini, pesantren dianggap sebagai salah satu sistem pendidikan tertua yang ada di Indonesia. Pondok pesantren sebagai institusi pendidikan yang berbasis agama memberi peran penting dalam membentuk generasi penerus yang tangguh dan sebagai agent of change. Oleh karenanya, pesantren mempunyai posisi yang sangat penting dalam menentukan perubahan dan perbaikan kualitas kehidupan di masyarakat.

Dalam perkembangannya, sampai saat ini pesantren terdapat beberapa tipe, diantaranya adalah pesantren salaf yang merupakan pesantren tradisonal, dan pesantren modern. Menurut Sudibyo (2006), data Departemen Agama tahun 2006 menunjukkan di Indonesia terdapat 16.015 pondok pesantren. Secara kelembagaan terdapat 3.991 (24,9\%) pondok pesantren salafiyah, 3.824 $(23,9 \%)$ pondok pesantren ashriyah dan $8.200(51,2 \%)$ pondok pesantren kombinasi. Jumlah santri secara keseluruhan sebanyak 3.190.394 jiwa yang terdiri dari $1.696 .494(53,2 \%)$ santri laki-laki dan 1.493 .900 (46,8\%) santri perempuan. Jumlah santri ini berdasarkan aktivitas belajar di pondok pesantren yang terdiri dari $38,2 \%$ santri yang menuntut ilmu agama saja dan sebagian besar 61,8\% dengan bersekolah. Masih menurut Sudibyo (2010) dari data tersebut, jika dilihat dari sebaran geografisnya, pondok pesantren ini sebagian besar berada di pedesaan 12.286 pondok pesantren $(83,83 \%)$, di perkotaan 1.240 pondok pesantren $(8,46 \%)$ dan di daerah transisi pedesaan-perkotaan 1.130 pondok pesantren $(7,71 \%)$. Selain sebagai lembaga pendidikan pondok pesantren juga melakukan aktivitas-aktivitas ekonomi, seperti perdagangan, agribisnis, kerajinan tangan dan jasa.

Tetapi sayangnya, akhir-akhir ini atau dalam satu dekade terakhir peran 
dan nama baik pesantren yang sudah ada selama beberapa abad mewarnai sistem pendidikan di Indonesia dinodai oleh adanya beberapa peristiwa yang terjadi. Tentu fenomena ini sangat bertolak belakang dengan kehidupan pesantren yang sesungguhnya. Pesantren sebagai salah satu sistem pendidikan tertua di Indonesia mempunyai ciri khas tersendiri. Pesantren hadir sebagai bagian dari lingkungan dan kehidupan masyarakat sekitarnya. Pesantren yang ada di tengah masyarakat memberikan warna dan ragam pada lingkungan dimana pesantren tersebut hadir. Pesantren yang ada di masyarakat juga tidak mencerminkan eksklusifitas yang memberi batas dengan lingkungan sekitarnya. Pesantren justru hidup membaur dan hidup berdampingan dengan lingkungan sekitarnya. Hal ini juga ditunjang dengan adanya masjid yang berada di pesantren tesebut, sehingga menambah keterikatan pesantren dengan masyarakat yang berada di sekitarnya, baik yang berada di pedesaan, perkotaan, maupun di daerah transisi, yang masing-masing mempunyai ciri khas tersendiri sebagai bagian dari masyarakat. Seperti yang terlihat pada pesantren dan masjid Gading di Kota Malang.

Masjid Gading Pesantren atau Masjid Baiturrahman Pondok Gading terletak di tengah Pondok Gading yang merupakan salah satu pondok pesantren yang cukup terkenal di Kota Malang. Masjid Gading Pesantren merupakan salah satu masjid di Kota Malang yang memiliki intensitas aktivitas yang tinggi, terutama aktivitas ibadah dan dakwah. Hal ini dikarenakan masjid ini berkembang bersama pesantren, para santri, dan para kyai yang ada di pesantren tersebut. Jangkauan jamaah masjid ini pun meliputi masyarakat setempat dan masyarakat Malang Raya secara umum.

Masjid ini menarik untuk diteliti karena kekhasannya sebagai masjid pesantren dengan intensitas kegiatan yang tinggi walaupun berdiri di atas lahan yang terbatas. Kegiatan-kegiatan keagamaan yang diselenggarakan di masjid ini seringkali meluas jauh melampaui wilayah teritori masjid itu sendiri. Interaksi yang terjadi antara warga pesantren dan masyarakat sekitar yang terjadi dalam berbagai kegiatan di masjid ini pun menarik untuk diteliti dari perspektif arsitektur perilaku, terutama dalam aspek teritorialitas ruang yang terjadi di masjid tersebut.

el Harakah Vol.15 No.2 Tahun 2013 


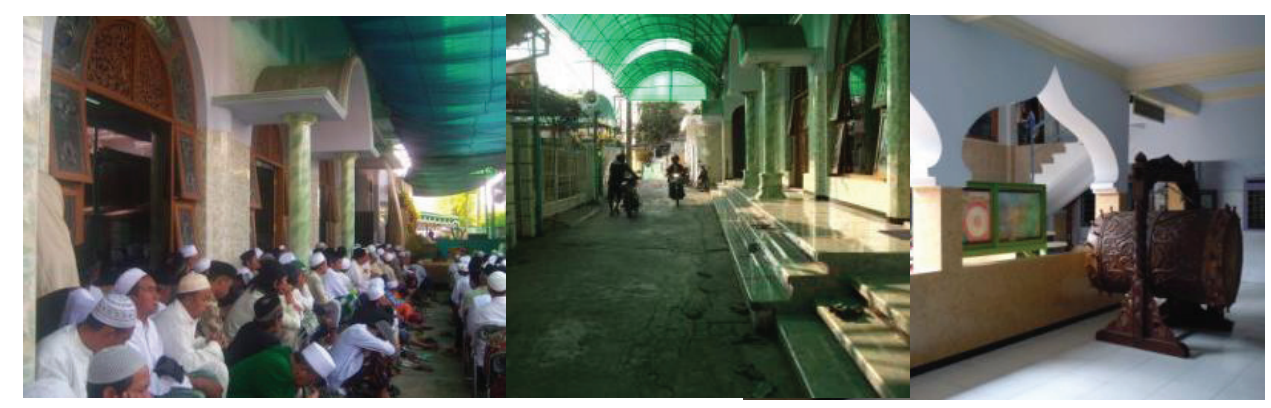

Gambar 1. Suasana Masjid Gading Pesantren

Penelitian ini merupakan bagian dari penelitian yang lebih besar mengenai teritorialitas ruang di masjid-masjid berbasis masyarakat. Masjid berbasis masyarakat dalam hal ini dimaksudkan sebagai masjid yang dirancang, dibangun, dan dipelihara berdasarkan inisiatif masyarakat setempat. Dalam kenyataannya, masjid-masjid semacam inilah yang hadir dan berkembang di sebagian besar wilayah di Indonesia. Masjid-masjid ini hadir tanpa campur tangan arsitek yang seringkali tidak terjangkau secara ekonomi oleh sebagian besar masyarakat kita. Masjid Gading Pesantren, seperti telah dijelaskan sebelumnya, merupakan salah satu masjid berbasis masyarakat yang khas karena dibangun dan berkembang di tengah-tengah warga pesantren yang menyatu dengan kehidupan masyarakat sekitarnya.

Tujuan dari penelitian ini adalah memetakan pola interaksi yang terjadi berdasarkan aktivitas dan perilaku spasial masyarakat setempat di lingkungan masjid. Dari sudut keilmuan arsitektur dan perilaku lingkungan, seting perilaku (behavior setting) diartikan sebagai suatu interaksi antara suatu kegiatan dengan tempat yang spesifik (Haryadi \& Setiawan, 2010: 27). Perilaku manusia dalam hubungannya dengan suatu seting fisik berlangsung secara konsisten sesuai waktu dan situasi. Karena itu, selalu terdapat pola perilaku yang khas untuk seting fisik itu yang dapat diidentifikasi. Penyebab dari terjadinya pola perilaku ini terkadang merupakan sesuatu yang tak kasat mata (Laurens, 2004: 19), sehingga memerlukan upaya penggalian dan interpretasi yang dapat mengungkap penyebab tersebut sebagai bagian dari kekayaan dan kedalaman penelitian. Dari penelitian ini ditemukan kekhasan-kekhasan pola interaksi yang terkait erat dan tampak dalam pola penggunaan ruang untuk berbagai aktivitas yang terjadi di lingkungan Masjid Gading Pesantren. Kekhasan-kekhasan pola perilaku dan pola penggunaan ruang inilah yang akan dipaparkan di dalam tulisan ini. 


\section{Metode}

Penelitian ini merupakan penelitian yang mengkaji pola interaksi yang terjadi berdasarkan perilaku spasial dan aktivitas suatu masyarakat di lingkungan masjid sebagai behavior setting-nya. Teknik pengumpulan data untuk jenis penelitian yang mengarah pada penelitian arsitektur berbasis perilaku ini adalah dengan (1) observasi langsung dan dokumentasi di lapangan untuk mengetahui langsung kondisi objek penelitian di lapangan, (2) wawancara, dan (3) melakukan pemetaan (mapping) perilaku yang terjadi dalam objek yang menjadi sampel penelitian. Pemetaan perilaku di dalam penelitian ini dilakukan dengan metode place centered mapping. Metode ini digunakan untuk mengetahui bagaimana manusia atau sekelompok manusia memanfaatkan, menggunakan atau mengakomodasikan perilakunya dalam situasi waktu dan tempat tertentu (Haryadi \& Setiawan, 2010: 82). Dalam place centered mapping ini, seluruh area masjid dibagi dalam tiga zona untuk memudahkan pengamatan, yaitu (1) zona ruang dalam, meliputi ruang haram atau ruang shalat utama, (2) zona peralihan, meliputi teras atau beranda masjid, (3) zona ruang luar meliputi halaman dan jalan yang masuk ke dalam area masjid.

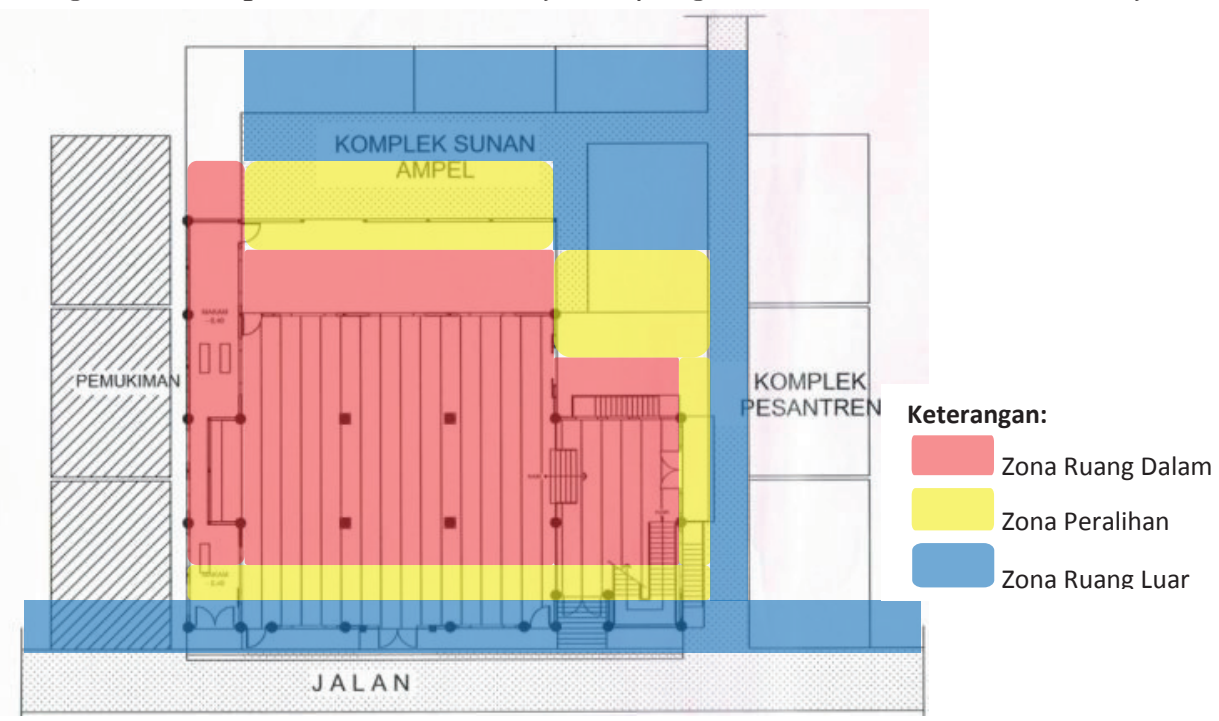

Gambar 2. Zonasi Pengamatan pada Masjid Gading Pesantren

Selain itu, metode time budget juga dipergunakan dalam place centered mapping ini untuk mengamati perilaku berdasarkan periode waktu. Waktu pengamatan akan mempengaruhi pengambilan data yang diamati, karena 
adanya pembagian waktu dalam 24 jam, dan terdapat waktu-waktu tertentu dalam mengamati objek dalam penelitian ini. Diharapkan akan terdapat perbedaan kondisi seting amatan dari perbedaan waktu amatan tersebut. Dalam penelitian ini, pengamatan dilakukan selama seminggu, sehingga masing-masing hari dalam seminggu cukup terwakili, termasuk hari Jum'at yang merupakan hari pelaksanaan shalat jum'at yang sangat penting di dalam Islam. Selain hari Jum'at, hari-hari libur seperti Sabtu dan Minggu juga cukup signifikan, karena pada hari-hari libur seperti ini biasanya diadakan berbagai kegiatan pengajian, akad nikah, dan sebagainya di masjid. Selanjutnya, pada masing-masing hari tersebut, waktu penelitian dibagi menjadi lima zona, sesuai dengan jumlah shalat fardhu berjamaah yang dilaksanakan di masjid. Pada masing-masing zona tersebut, rentang waktu yang digunakan adalah satu atau setengah jam sebelum shalat, setengah jam di sekitar waktu shalat, dan satu atau setengah jam setelah shalat. Perkecualian dari pengaturan waktu ini adalah untuk rentang waktu setelah shalat magrib yang digabung dengan rentang waktu sebelum shalat isya. Hal ini dikarenakan sempitnya waktu di antara pelaksanaan kedua shalat fardhu tersebut. Gambar 2 berikut ini adalah dua contoh dari 98 lembar dokumen place centered mapping sebagai hasil pengamatan di Masjid Gading Pesantren.

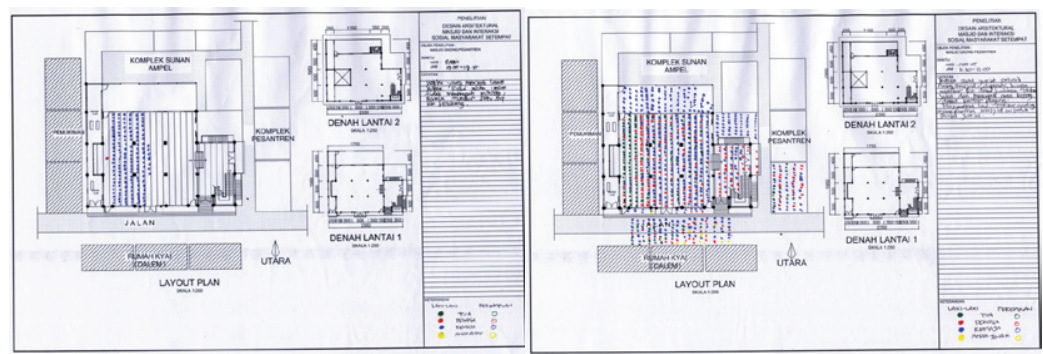

Gambar 3. Contoh dokumen place centered mapping pada Masjid Gading Pesantren

\section{Hasil Penelitian}

Hasil dari penelitian ini dipaparkan dalam bentuk tabel pemetaan perilaku yang berasal dari dokumen place centered mapping untuk Masjid Gading Pesantren sebagai hasil pengamatan selama seminggu penuh pada waktu-waktu yang telah ditentukan di dalam time budget penelitian ini. Selama proses penerjemahan dokumen place centered mapping ke dalam bentuk tabel pemetaan perilaku inilah, peneliti mampu menemukan pola-pola perilaku yang terjadi, sekaligus kekhasan-kekhasan pola perilaku dan pola penggunaan 
ruang yang terjadi di Masjid Gading Pesantren. Tabel 1 berikut ini merupakan salah satu tabel yang memberikan penjelasan singkat dan terstruktur dalam satu hari pengamatan.

Tabel 1. Pemetaan perilaku di Masjid Gading Pesantren pada hari pertama pengamatan

\begin{tabular}{|c|c|c|c|}
\hline \multirow[b]{2}{*}{ Waktu } & \multicolumn{3}{|c|}{ Aktivitas } \\
\hline & Zona Ruang Dalam & $\begin{array}{c}\text { Zona } \\
\text { Peralihan }\end{array}$ & $\begin{array}{c}\text { Zona Ruang } \\
\text { Luar }\end{array}$ \\
\hline $\begin{array}{l}\text { Sebelum } \\
\text { subuh } \\
04.00-04.15\end{array}$ & $\begin{array}{l}\text {-Jamaah melaksanakan shalat } \\
\text { sunnah dan berdzikir. } \\
\text {-Sebagian besar jamaah merupakan } \\
\text { remaja, dan mengambil tempat di } \\
\text { sebelah kanan ruang shalat, dekat } \\
\text { dengan dinding atau kolom. } \\
\text { - Menjelang shalat para jamaah } \\
\text { mengumandang-kan shalawat }\end{array}$ & Tidak ada & Tidak ada \\
\hline $\begin{array}{l}\text { Ketika subuh } \\
04.15-04.30\end{array}$ & $\begin{array}{l}\text { - Shalat berjamaah terdiri dari } \\
\text { sembilan shaf laki-laki. } \\
\text {-Jamaah yang awalnya hanya } \\
\text { beberapa shaf terus bertambah } \\
\text { hingga akhir waktu shalat. }\end{array}$ & Tidak ada & Tidak ada \\
\hline $\begin{array}{c}\text { Sesudah subuh } \\
04.30-05.00\end{array}$ & $\begin{array}{l}\text { - Jamaah tetap berada di tempatnya } \\
\text { semula, dan mengumandangkan } \\
\text { dzikir dan tahlil dengan dipimpin } \\
\text { oleh kyai. }\end{array}$ & Tidak ada & Tidak ada \\
\hline $\begin{array}{l}\text { Sebelum } \\
\text { dzuhur } \\
11.20-11.30\end{array}$ & $\begin{array}{l}\text {-Jamaah yang sebagian besar warga } \\
\text { pondok ketika memasuki masjid } \\
\text { langsung menuju pojok utara dan } \\
\text { berkerumun di sana. } \\
\text { - Jamaah menunggu waktu shalat } \\
\text { dengan duduk dan berdzikir. }\end{array}$ & Tidak ada & Tidak ada \\
\hline $\begin{array}{l}\text { Ketika dzuhur } \\
11.30-11.45\end{array}$ & $\begin{array}{l}\text { - Shalat berjamaah terdiri dari satu } \\
\text { shaf laki-laki, sebagian besar remaja } \\
\text { putra. }\end{array}$ & Tidak ada & Tidak ada \\
\hline $\begin{array}{c}\text { Setelah dzuhur } \\
11.45-12.15\end{array}$ & $\begin{array}{l}\text { - Beberapa jamaah mengambil posisi } \\
\text { di dekat-dekat kolom dan dinding. } \\
\text {-Jamaah di shaf pertama hanya } \\
\text { sedikit yang berpindah tempat }\end{array}$ & Tidak ada & $\begin{array}{l}\text { - Beberapa } \\
\text { jamaah } \\
\text { berjalan } \\
\text { pulang sambil } \\
\text { mengobrol }\end{array}$ \\
\hline
\end{tabular}




\begin{tabular}{|c|c|c|c|}
\hline $\begin{array}{c}\text { Sebelum ashar } \\
14.15-14.45\end{array}$ & $\begin{array}{l}\text { - Sambil menunggu kedatangan kyai, } \\
\text { para jamaah berdzikir, membaca } \\
\text { al Quran dan mengumandangkan } \\
\text { shalawat. }\end{array}$ & Tidak ada & Tidak ada \\
\hline $\begin{array}{l}\text { Ketika ashar } \\
14.45-15.00\end{array}$ & $\begin{array}{l}\text { - Shalat berjamaah terdiri dari satu } \\
\text { setengah shaf laki-laki, sebagian } \\
\text { besar remaja putra. }\end{array}$ & Tidak ada & Tidak ada \\
\hline $\begin{array}{l}\text { Setelah ashar } \\
15.00-15.30\end{array}$ & $\begin{array}{l}\text { - Setelah shalat berjamaah, para } \\
\text { jamaah melakukan dzikir bersama } \\
\text { yang dipimpin oleh kyai. } \\
\text { - Setelah itu jamaah meninggalkan } \\
\text { masjid, namun beberapa jamaah } \\
\text { masih berada di masjid untuk } \\
\text { membaca al Quran }\end{array}$ & Tidak ada & $\begin{array}{l}\text { - Beberapa } \\
\text { jamaah } \\
\text { berjalan } \\
\text { pulang sambil } \\
\text { mengobrol }\end{array}$ \\
\hline $\begin{array}{l}\text { Sebelum } \\
\text { maghrib } \\
17.00-17.30\end{array}$ & $\begin{array}{l}\text { - Beberapa jamaah duduk di dekat } \\
\text { dinding dan kolom menunggu } \\
\text { datangnya waktu shalat sambil } \\
\text { berdzikir. }\end{array}$ & Tidak ada & $\begin{array}{l}\text { - Para jamaah } \\
\text { datang secara } \\
\text { beramai-ramai } \\
\text { ketika kyai } \\
\text { memasuki } \\
\text { ruang shalat } \\
\text { masjid. }\end{array}$ \\
\hline $\begin{array}{c}\text { Ketika } \\
\text { maghrib } \\
17.30-17.45\end{array}$ & $\begin{array}{l}\text {-Shalat jamaah terdiri dari } 7 \text { shaf } \\
\text { awal dan } 2 \text { shaf makmum masbuk, } \\
\text { sebagian besar adalah jamaah } \\
\text { remaja pria. }\end{array}$ & Tidak ada & $\begin{array}{l}\text { - Selama shalat } \\
\text { berlangsung } \\
\text { masih cukup } \\
\text { banyak } \\
\text { jamaah yang } \\
\text { berdatangan } \\
\text { menuju } \\
\text { masjid. }\end{array}$ \\
\hline $\begin{array}{l}\text { Setelah } \\
\text { maghrib dan } \\
\text { sebelum isya } \\
17.45-18.40\end{array}$ & $\begin{array}{l}\text {-Jamaah yang berada di shaf } \\
\text { pertama dan kedua hampir tidak } \\
\text { bergeser dari tempatnya, namun } \\
\text { jamaah shaf ketiga dan seterusnya } \\
\text { menyebar ke pojok-pojok ruang } \\
\text { shalat atau bersan-dar di kolom- } \\
\text { kolom. } \\
\text { - Beberapa jamaah tetap berada di } \\
\text { masjid hingga tiba waktu shalat isya }\end{array}$ & Tidak ada & $\begin{array}{l}\text { - Sebagian } \\
\text { jamaah } \\
\text { langsung } \\
\text { berjalan } \\
\text { meninggalkan } \\
\text { masjid setelah } \\
\text { berdzikir. }\end{array}$ \\
\hline $\begin{array}{c}\text { Ketika isya } \\
18.40-18.55\end{array}$ & $\begin{array}{l}\text {-Shalat jamaah terdiri dari } 8 \text { shaf, } \\
\text { sebagian besar adalah jamaah } \\
\text { remaja pria. }\end{array}$ & Tidak ada & Tidak ada \\
\hline
\end{tabular}




\begin{tabular}{|c|l|l|l|}
\hline $\begin{array}{c}\text { Setelah isya } \\
19.00-19.30\end{array}$ & $\begin{array}{l}\text {-Jamaah melakukan dzikir bersama } \\
\text { yang dipimpin oleh kyai, lalu } \\
\text { kembali ke pondok }\end{array}$ & Tidak ada & Tidak ada \\
\hline
\end{tabular}

Sumber: Hasil Analisis, 2010

Dari tabel-tabel pemetaan perilaku, pengamatan langsung, foto-foto dokumentasi, serta wawancara yang telah dilakukan, dapat diperoleh temuan yang berkaitan dengan pola perilaku jamaah Masjid Gading Pesantren, sebagai berikut:

1. Aktivitas yang terus-menerus terulang di masjid ini adalah aktivitas keagamaan (shalat berjamaah, berdzikir, pelajaran mengaji, pengajian umum) dan aktivitas sosial (silaturahmi, berbincang-bincang, beristirahat, bermain).

2. Aktivitas-aktivitas ibadah, pengajian, pengajaran al Quran, dan diskusi lebih banyak dilakukan di dalam ruang shalat utama, sedangkan teras dan halaman hanya difungsikan sebagai tempat beristirahat, mengobrol, bermain, dan perluasan area shalat di waktu Shalat Jum'at.

3. Jamaah masjid pada hari-hari biasa sebagian besar merupakan santri putra yang berasal dari pondok. Hanya terdapat sedikit sekali pendatang (musafir) yang mengikuti shalat berjamaah di masjid ini. Walaupun demikian, pada waktu shalat Jum'at, masjid ini penuh sesak oleh jamaah yang terdiri dari masyarakat setempat yang berbaur dengan santri putra dari pondok.

4. Jamaah santri putra ketika berada di masjid langsung menuju ruang shalat utama dan melakukan berbagai aktivitas ibadah di dalamnya. Sementara itu, jamaah yang berasal dari pendatang memiliki kecenderungan untuk duduk dan menunggu di teras depan (selatan) ruang shalat.

5. Pada saat kyai berhalangan memimpin shalat berjamaah, shalat berjamaah dipimpin oleh salah satu ustadz pondok. Shaf shalat berjamaah dimundurkan satu shaf karena imam tidak menggunakan mihrab, melainkan mundur satu shaf di belakang mihrab (Gambar 3 kiri). Ketika kyai memimpin shalat berjamaah, posisi imam dan makmum kembali seperti biasa.

6. Tidak disediakan area khusus shalat untuk wanita pada hari-hari biasa. Namun, pada hari-hari tertentu dimana terdapat pengajian umum, pembatas antara jamaah pria dan wanita dipasang berupa kain yang dibentangkan mulai dari area mihrab hingga area belakang ruang shalat. Jamaah santri putri menempati area di sebelah kiri mihrab, sedangkan jamaah santri putra menempati area di sebelah kanan mihrab.

Salah satu elemen yang cukup penting di masjid tersebut adalah keberadaan 
makam para kyai pesantren yang terletak di sebelah kiri dan kanan mihrab. Pada beberapa waktu dalam seminggu, area di sekitar makam digunakan para santri, ustadz, dan kyai untuk beristighotsah.

Di antara elemen-elemen arsitektural yang signifikan bagi perilaku jamaah adalah (1) dinding dan kolom yang sering dijadikan sandaran ketika berdzikir, mendengarkan ceramah, dan dijadikan pula pembatas vertikal (sutrah) ketika shalat sunah secara sendiri-sendiri, (2) tangga teras depan merupakan tempat favorit yang digunakan musafir untuk menunggu waktu shalat berjamaah, (3) teras, tangga, dan halaman merupakan tempat favorit bagi anak-anak untuk bermain-main.

Pemanfaatan lantai atas (lantai dua) masjid ini tidak ditemukan selama penelitian. Saat shalat Jum'at pun lantai dua ini tidak digunakan, karena jamaah lebih memilih melakukan shalat di teras masjid hingga ke jalan dan area halaman rumah kyai.

\section{Pembahasan}

Dari pemaparan hasil penelitian ini, terdapat beberapa hal yang menarik untuk dibahas secara mendalam, terutama dalam aspek teritorialitas ruang dan seting perilaku di dalam bidang keilmuan arsitektur perilaku. Pertama, adanya perbedaan pola perilaku di zona-zona yang berbeda di masjid yang telah diteliti. Sikap yang berbeda ditunjukkan oleh sebagian besar jamaah ketika berada di ruang shalat utama (zona ruang dalam) dan area teras (zona peralihan). Di area ruang shalat utama para jamaah cenderung lebih menjaga sikap dengan duduk bersila, berbicara dengan suara pelan, dan jika bersandar tidak mengarahkan kaki ke arah kiblat. Sementara itu, sikap yang lebih informal dapat diamati di area teras masjid. Para jamaah terlihat lebih santai dengan duduk berselonjor, berbicara dengan suara lebih nyaring, menelepon, atau bercanda dengan kelompoknya.

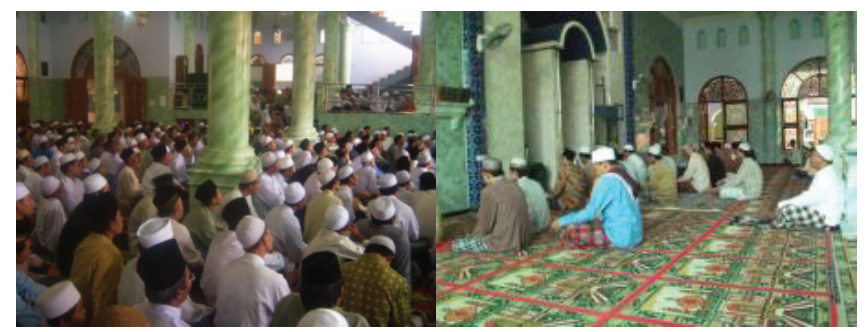

Gambar 4. Sikap para jamaah di zona ruang dalam Masjid Gading Pesantren

Fenomena perbedaan perilaku pada masing-masing zona ini dapat dijelaskan dari sudut pandang teritorialitas dan hirarki ruang sosial. Di dalam 
konsep teritorialitas yang dikemukakan oleh Altman, terdapat tiga kategori teritori, yaitu teritori primer, teritori sekunder, dan teritori publik, dikaitkan dengan keterlibatan personal, involvement, kedekatan dengan kehidupan sehari-hari individu atau kelompok, dan frekuensi penggunaan. Teritori utama (primer) adalah suatu area yang dimiliki, digunakan secara eksklusif, disadari oleh orang lain, dikendalikan secara permanen serta menjadi bagian utama dalam kehidupan sehari-hari penghuninya. Teritori sekunder adalah suatu area yang tidak terlalu digunakan secara eksklusif oleh seseorang/kelompok orang, mempunyai cakupan area yang relatif luas, dikendalikan secara berkala oleh kelompok yang menuntutnya. Teritori publik adalah suatu lingkungan kampung yang batas fisiknya relatif jelas (Altman, 1975).

Kecenderungan untuk bersikap lebih informal, santai, dan terbuka di teritori-teritori sekunder dan tersier disebabkan teritori ini dianggap merupakan milik bersama yang tidak eksklusif dan tidak terikat oleh sejumlah peraturan yang biasanya terdapat di teritori primer. Teritori primer dari masjid yang meliputi mihrab dan ruang shalat utama (zona ruang dalam), seperti telah kita ketahui, terikat oleh ketentuan-ketentuan fikih dan adab (etika) yang mengatur tata perilaku kaum muslim di dalam masjid. Karena itu, walaupun tidak ada otoritas yang secara rutin dan terstruktur mengawasi penggunaan ruang-ruang dalam ini, kaum muslim yang telah memiliki pengetahuan dan pemahaman mengenai ketentuan-ketentuan fikih dan adab tersebut secara sadar mengatur perilakunya masing-masing. Perilaku di masing-masing teritori masjid ini juga menunjukkan bahwa semakin rendah tingkatan teritori masjid, yaitu teritori publik, maka semakin sifatnya akan semakin profan (umum), dan semakin tinggi tipe teritori yang terbentuk (teritori primer), sifatnya menjadi lebih sakral.

Satu hal yang menarik untuk diungkapkan adalah dapat diamatinya bias perilaku yang berkaitan dengan adab yang sebenarnya berlaku secara umum, namun hanya dianggap berlaku di dalam ruang masjid, yaitu kebiasaan membuang sampah sembarangan. Satu fenomena yang tertangkap dalam penelitian ini adalah adanya jamaah yang mencegah dirinya dari membuang sampah sembarangan di dalam ruang masjid, namun membuangnya sembarangan ke jalan di samping masjid. Kecenderungan perilaku semacam ini pada umumnya disebabkan kurangnya pemahaman kaum muslim mengenai adab, yang selain adab terhadap Allah SWT dan sesama manusia, terdapat pula adab kepada makhluk-makhluk lain dan alam semesta sebagai ciptaan Allah.

Kedua, pola perilaku yang berbeda terhadap masing-masing teritori juga ditunjukkan oleh warga pesantren dan masyarakat setempat, dengan jamaah 
yang tidak berasal dari lingkungan sekitar. Jamaah yang berasal dari warga pesantren dan masyarakat setempat telah menganggap masjid sebagai bagian dari teritori mereka (teritori sekunder). Sementara itu, jamaah yang berasal dari luar lingkungan sekitar menganggap masjid bukan merupakan teritori mereka. Karena itu, perilaku mereka menunjukkan bahwa mereka merasa lebih nyaman untuk beraktivitas di zona ruang luar atau zona peralihan (teritori publik). Hal ini menarik, karena sebagai bangunan atau fasilitas publik masjid sebenarnya 'dimiliki' oleh seluruh masyarakat muslim. Namun fenomena ini juga sangat wajar terjadi karena perilaku seseorang di wilayah-wilayah yang asing baginya biasanya sangat dipengaruhi oleh persepsi awalnya terhadap wilayah tersebut. Sebaliknya, jika wilayah tersebut telah sering didatangi, persepsi awal tersebut tidak lagi menjadi hal utama yang mempengaruhi perilakunya, dan ia akan lebih dipengaruhi oleh teritorialitas yang telah muncul di dalam dirinya.

Ketiga, pola perilaku lain yang juga khas di Masjid Gading Pesantren, adalah pola perilaku santri dan warga pesantren yang secara rutin melakukan shalat berjamaah lima waktu di masjid ini. Area mihrab yang ada di masjid tersebut hanya digunakan oleh kyai yang menjadi imam. Pada saat kyai berhalangan hadir, shalat berjamaah dipimpin oleh salah satu ustadz pondok. Shaf shalat berjamaah dimundurkan satu shaf karena imam tidak menggunakan mihrab, melainkan mundur satu shaf di belakang mihrab. Ketika kyai memimpin shalat berjamaah, posisi imam dan makmum kembali seperti biasa. Adanya pola perilaku ini menunjukkan adanya teritori primer yang terbentuk di wilayah mihrab. Area mihrab ini membentuk teritori primer karena digunakan secara eksklusif oleh kyai yang menjadi imam, dan disadari oleh para santri serta masyarakat yang menjadi makmum, serta dikendalikan secara permanen serta menjadi bagian utama dalam kegiatan shalat sehari-hari.

Hal menarik yang dapat diamati dari pola perilaku ini adalah ketiadaan 'pemilik' teritori tidak menyebabkan adanya perubahan perilaku pada diri santri dan jamaah. Mereka tetap menghormati peran kyai sebagai pemilik teritori primer tersebut, dengan tidak memanfaatkan mihrab sama sekali di saat kyai tidak berada di tempat. Mereka memilih untuk tetap melakukan shalat berjamaah dengan posisi imam satu shaf di belakang mihrab. Hal ini tentu saja tidak terkait dengan ketentuan fikih shalat berjamaah, namun lebih terkait dengan adanya adab terhadap kyai sebagai pemimpin institusi masjid dan pesantren. 


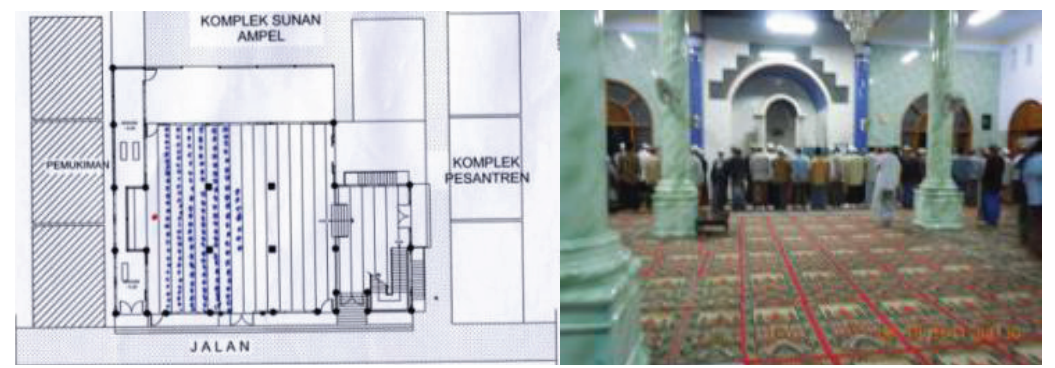

Gambar 5. Pemunduran satu shaf imam dan jamaah di Masjid Gading Pesantren

Pada kondisi umum, perilaku keruangan seseorang atau sekelompok orang biasanya menunjukkan perbedaan jika orang atau tokoh yang dihormati sedang berada atau sedang tidak ada di lingkungan mereka. Seseorang atau sekelompok orang cenderung untuk lebih menjaga sikap dan mengatur posisi ketika sedang berada di sekitar orang yang mereka hormati. Sikap dan posisi tersebut kembali pada keadaan semula jika orang yang mereka hormati itu tidak berada di sekitar mereka lagi. Namun, kondisi yang berbeda dapat kita amati pada perilaku keruangan santri dan jamaah di masjid ini. Keberadaan atau ketiadaan kyai sebagai tokoh yang dihormati di masjid dan pesantren ini tidak seluruhnya mempengaruhi perilaku keruangan para santri. Mereka tetap menunjukkan penghormatan dan adab kepada sang kyai melalui perilaku keruangan mereka, walaupun sang kyai tidak berada bersama mereka. Dengan demikian, teritori primer yang ada ini tetap diakui dan dilegitimasi oleh seluruh jamaah masjid dan mempengaruhi pola perilaku keruangan mereka sehari-hari.

\section{Simpulan}

Perilaku keruangan yang khas disebabkan adanya adab terhadap suatu tempat atau seseorang dapat kita amati dengan jelas pada penelitian ini. Perilaku-perilaku keruangan yang didasari keyakinan akan adanya adab yang harus dijaga terhadap sebuah tempat atau seseorang yang dihormati ini bahkan tidak mensyaratkan adanya pengawasan langsung dari otoritas tempat yang bersangkutan atau keberadaan orang yang dihormati tersebut. Namun, perilaku-perilaku keruangan untuk mewujudkan adab dan rasa hormat tersebut tidak selalu sama di tiap masjid atau di tiap tempat. Perilaku-perilaku keruangan yang telah menjadi kebiasaan atau tradisi seperti yang dapat diamati pada Masjid Gading Pesantren ini merupakan kekhasan tersendiri yang tidak ditemui di banyak 
tempat lainnya, terutama di masjid-masjid yang tidak dikelola oleh pesantren. Perilaku-perilaku keruangan lainnya yang khas juga mungkin dapat ditemukan di masjid-masjid lain yang berbeda dengan yang teramati di Masjid Gading Pesantren ini. Kekhasan perilaku keruangan ini dapat dianggap sebagai local wisdom yang diterima secara luas keberadaannya di dalam Islam selama tidak bertentangan dengan syariat.

Selanjutnya, sebagai saran bagi penelitian selanjutnya adalah munculnya pula kecenderungan penyimpangan perilaku-perilaku keruangan di masjidmasjid beberapa tahun terakhir. Melalui pengamatan awal terhadap beberapa masjid di beberapa tempat, banyak pula perilaku-perilaku keruangan yang tidak lagi memperhatikan adab terhadap masjid maupun adab terhadap sesama manusia. Salah satu contohnya adalah adanya masjid-masjid yang digunakan sebagai tempat bermesraan oleh para muda-mudi. Penelitian lanjutan mengenai adanya kecenderungan penyimpangan perilaku keruangan di masjid yang sesungguhnya merupakan tempat ibadah ini sangat diperlukan untuk menyingkap tidak hanya pola keruangan yang menunjukkan penyimpangan tersebut, namun juga alasan-alasan di balik munculnya penyimpangan perilaku keruangan tersebut, serta strategi-strategi arsitektural yang dapat ditempuh dalam perancangan masjid di masa depan yang dapat mengantisipasi adanya penyimpangan perilaku keruangan semacam ini.

\section{Daftar Pustaka}

Altman, I. 1975. The Environment and Social Behavior. Monterey, CA: Wadsworth.

Haryadi \& Setiawan, B. 2010. Arsitektur, Lingkungan dan Perilaku: Pengantar ke Teori, Metodologi dan Aplikasi. Yogyakarta: Gadjah Mada University Press.

Laurens, JM. 2004. Arsitektur dan Perilaku Manusia. Surabaya: PT. Grasindo.

Sudibyo, Rahmad Pulung, 2010, Integrasi, Sinergi Dan Optimalisasi Dalam Rangka Mewujudkan Pondok Pesantren Sebagai Pusat Peradaban Muslim Indonesia e Journal diakses tanggal 25 Juni 2011. 